\title{
THE LIVER LIPIDS IN NORMAL HUMAN LIVERS AND IN CASES OF CIRRHOSIS AND FATTY INFILTRATION OF THE LIVER
}

\author{
BY ELAINE P. RALLI, SAUL H. RUBIN AND SEYMOUR RINZLER \\ (From the Department of Medicine, New York University and the Third (New York \\ University) Medical Division, Bellevue Hospital, New York)
}

(Received for publication September 30, 1940)

The distribution of lipids in the liver has been studied rather thoroughly during the past 10 years but most of the observations have been on the livers of normal or diabetic dogs $(1,2,3)$ and on rats $(4,5)$. Reports of the fat content of human livers, either normal or pathological, have in comparison been limited $(6,7,8)$. Such analyses on human livers are of increasing interest because the experimental studies on the production of fatty livers in animals have suggested not only new etiological factors but also means by which fatty infiltration of the liver might be prevented $(9,10)$. One factor obviously capable of influencing the deposition of fat in the liver is the external secretion of the pancreas. This has been shown by the fact that, when the pancreatic ducts were ligated in dogs, marked fatty infiltration of the liver occurred $(11,12)$. This fatty infiltration was not accompanied by any demonstrable disturbance of carbohydrate metabolism but was similar in degree and type to the fatty infiltration of the liver observed in the depancreatized dog. In both the dog with the ligated duct and the depancreatized animal choline in doses of 2 grams daily was capable of preventing the deposition of fat in the liver. Recently we observed another interesting fact (13), namely, that regardless of the pathological state of the dog, fatty infiltration of the liver did not occur if in place of whole meat the dogs were fed a diet containing the dried meat powder from which the water-soluble extractives had been removed.

In humans, fatty livers have been observed at postmortem in cases of chronic alcoholism, diabetes mellitus, marked obesity and occasionally in certain endocrine disorders. The great majority of such observations have been based on the gross and microscopic appearance of the livers. Chemical analysis of the liver gives not only a more exact idea of the total amount of lipid but it is the only means of determining the nature of the lipid changes that may have taken place.
TABLE I

The rate of change in the analytical values of the lipids of a normal, intact dog liver kept in refrigerator

\begin{tabular}{c|r|c|c|c|c|c}
\hline \hline $\begin{array}{c}\text { Sample } \\
\text { num- } \\
\text { ber }\end{array}$ & $\begin{array}{c}\text { Time } \\
\text { elapsed }\end{array}$ & $\begin{array}{c}\text { Total } \\
\text { lipids }\end{array}$ & $\begin{array}{c}\text { Total } \\
\text { fatty } \\
\text { acids }\end{array}$ & $\begin{array}{c}\text { Total } \\
\text { choles- } \\
\text { terol }\end{array}$ & $\begin{array}{c}\text { Phospho- } \\
\text { lipids }\end{array}$ & $\begin{array}{c}\text { Neutral } \\
\text { fat }\end{array}$ \\
\cline { 2 - 6 } & hours & per cent & per cent & $\begin{array}{c}\text { mgm. } \\
\text { per cent }\end{array}$ & per cent & per cent \\
1 & 0.5 & 3.41 & 2.36 & 239 & 2.30 & 0.87 \\
2 & 4.5 & 3.45 & 2.43 & 241 & 2.19 & 1.02 \\
3 & 23.0 & 3.19 & 2.29 & 231 & 1.82 & 1.13 \\
4 & 46.0 & 3.36 & 2.45 & 245 & 1.80 & 1.32 \\
\hline
\end{tabular}

PROCEDURE

In this study we wished to reexamine the earlier observations of the lipid content and distribution in normal human livers and, in addition, to study the changes that might occur as a result of liver damage. The normal group consisted of 25 subjects killed in accidents in whom no gross pathological findings were observed at autopsy except those connected with the immediate cause of death. The pathological group consisted of 25 patients with well established histories and evidences of chronic alcoholism and 5 cases of cirrhosis of the liver with no history of alcoholism. Liver samples were obtained in most of the cases within 24 hours after death. In order to check the effect of any postmortem changes on the various lipid fractions, fresh specimens of dog liver were kept in the ice box and determinations were done at intervals of $1 / 2,4 \frac{1}{2}, 23$ and 46 hours (Table I). The only significant change found was in the apparent concentration of phospholipids (calculated as lecithin) and of neutral fat, which is discussed later. Lipids and their fractions were done by the methods previously described from this laboratory (1).

\section{RESULTS}

The normal group (Table II) consisted of 20 males and 5 females. The ages varied from 4 to 81 years. The average total liver lipid for the group was 4.98 grams per 100 grams of wet liver. The range was from 2.42 to 8.41 grams per cent. In 19 of the cases the total lipid did not exceed 5.41 grams per cent. In all probability in the normal liver the concentration of total lipid will not exceed 8 grams per cent. This corresponds with the values reported by Breusch and Scala- 
TABLE II

Liver lipids in normal subjects

\begin{tabular}{|c|c|c|c|c|c|c|c|c|c|}
\hline \multirow{2}{*}{$\begin{array}{c}\text { Case } \\
\text { number }\end{array}$} & \multirow{2}{*}{ Age } & \multirow{2}{*}{ Sex } & \multirow{2}{*}{$\begin{array}{l}\text { Liver } \\
\text { weight }\end{array}$} & \multirow{2}{*}{$\begin{array}{l}\text { Total } \\
\text { lipids }\end{array}$} & \multirow{2}{*}{$\begin{array}{l}\text { Fatty } \\
\text { acids }\end{array}$} & \multicolumn{2}{|c|}{ Cholesterol } & \multirow{2}{*}{$\begin{array}{l}\text { Phos- } \\
\text { pho- } \\
\text { lipids }\end{array}$} & \multirow{2}{*}{$\begin{array}{c}\text { Neu- } \\
\text { tral } \\
\text { fat }\end{array}$} \\
\hline & & & & & & Free & Total & & \\
\hline \multirow{24}{*}{$\begin{array}{r}8 \\
12 \\
15 \\
16 \\
17 \\
4 \\
35 \\
47 \\
49 \\
50 \\
69 \\
60 \\
61 \\
63 \\
71 \\
72 \\
76 \\
77 \\
80 \\
81 \\
85 \\
89 \\
90 \\
94 \\
100\end{array}$} & \multirow{24}{*}{$\begin{array}{l}50 \\
30 \\
10 \\
74 \\
35 \\
34 \\
45 \\
30 \\
55 \\
40 \\
59 \\
55 \\
18 \\
14 \\
62 \\
55 \\
4 \\
35 \\
39 \\
49 \\
35 \\
45 \\
81 \\
50 \\
39\end{array}$} & \multirow{24}{*}{$\begin{array}{l}\mathbf{M} \\
\mathbf{M} \\
\mathbf{M} \\
\mathbf{F} \\
\mathbf{M} \\
\mathbf{M} \\
\mathbf{M} \\
\mathbf{M} \\
\mathbf{M} \\
\mathbf{M} \\
\mathbf{F} \\
\mathbf{M} \\
\mathbf{F} \\
\mathbf{M} \\
\mathbf{M} \\
\mathbf{M} \\
\mathbf{M} \\
\mathbf{F} \\
\mathbf{M} \\
\mathbf{M} \\
\mathbf{M} \\
\mathbf{M} \\
\mathbf{M} \\
\mathbf{M} \\
\mathbf{F}\end{array}$} & grams & $\begin{array}{l}\text { grams } \\
\text { per }\end{array}$ & $\begin{array}{l}\text { grams } \\
\text { per }\end{array}$ & $\underset{\text { per }}{\operatorname{mggm}}$. & $\begin{array}{c}\mathrm{mgm} \\
\mathrm{per}\end{array}$ & $\begin{array}{c}\text { grams } \\
\text { per }\end{array}$ & $\begin{array}{c}\text { grams } \\
\text { per }\end{array}$ \\
\hline & & & 1500 & 3.26 & 2.34 & 197 & 247 & 2.42 & 1.35 \\
\hline & & & 1250 & 8.41 & 6.98 & 199 & & 1.81 & 6.0 \\
\hline & & & 950 & 3.55 & 2.25 & & 297 & 1.73 & 1.12 \\
\hline & & & 1200 & 6.35 & 4.30 & & 296 & 2.53 & 2.72 \\
\hline & & & 1300 & 4.92 & 2.98 & & 388 & 2.34 & 1.38 \\
\hline & & & 1760 & 4.25 & 2.69 & 217 & 249 & 3.03 & 0.69 \\
\hline & & & 1630 & 4.42 & 3.54 & & 240 & 2.42 & 2.03 \\
\hline & & & 1820 & 2.42 & 1.62 & & 256 & 1.47 & 0.63 \\
\hline & & & 1800 & 6.22 & 4.37 & & 309 & 2.54 & 2.70 \\
\hline & & & 1670 & 5.41 & 2.38 & & 261 & 2.57 & 0.69 \\
\hline & & & 1370 & 4.08 & 2.68 & & & 1.94 & 1.40 \\
\hline & & & 1780 & 8.50 & 7.22 & & & 1.46 & 6.5 \\
\hline & & & 1200 & 4.81 & 3.06 & & & 2.16 & 1.67 \\
\hline & & & 1100 & 3.55 & 2.16 & & & 1.53 & 1.17 \\
\hline & & & 1500 & 4.26 & 2.95 & & & 1.67 & 1.90 \\
\hline & & & 1620 & 6.49 & 5.05 & & & 1.68 & 4.1 \\
\hline & & & $\begin{array}{r}530 \\
1170\end{array}$ & $\begin{array}{l}5.03 \\
4.44\end{array}$ & $\begin{array}{l}3.38 \\
2.88\end{array}$ & & & & \\
\hline & & & 1500 & $\begin{array}{l}4.44 \\
4.65\end{array}$ & $\begin{array}{l}2.00 \\
3.18\end{array}$ & & & & \\
\hline & & & 1450 & 5.01 & 3.37 & & & & \\
\hline & & & 1640 & 3.51 & 2.54 & & & & \\
\hline & & & 1470 & 3.44 & 2.49 & & & & \\
\hline & & & 1410 & 5.29 & 3.62 & & & & \\
\hline & & & $\begin{array}{l}1540 \\
1300\end{array}$ & $\begin{array}{l}8.02 \\
4.10\end{array}$ & $\begin{array}{l}6.89 \\
2.68\end{array}$ & & & & \\
\hline & & & & & 350 & 204 & 283 & 208 & 226 \\
\hline & & & & & & & & & \\
\hline
\end{tabular}

brino (7) and by Kennaway and Leathes (8). It is also the upper limit of the liver lipid in normal dogs (1). Total cholesterol determinations were done in 9 of these cases. The average was 283 mgm. per cent. In 2 cases the total was over 300 mgm. per cent. The greater portion of cholesterol in the liver is present normally as free cholesterol (1). Neutral fat and lecithin determinations were done in 16 of the cases. The lecithin averaged 2.08 grams per cent, with a range from 1.46 to 2.57 grams per cent. The average value for neutral fat was 2.26 grams per cent with a range from 0.69 to 6.54 grams per cent. In only 2 cases was the concentration over 6 grams per cent and in only 2 cases was the concentration as low as 0.69 gram per cent. As one would expect, the higher neutral fat values were found in the cases with total lipids at the upper level, e.g., 8 grams per cent. The total liver lipid in a normal individual may reflect to some extent the nutritional state or it may be related to the ingestion of food, particularly fatty foods.

In the group of 25 patients with alcoholic his- tories (Table III) the findings in the livers present certain striking changes. The total lipid was elevated above 9 grams per cent in 13 cases, the highest being 34.8 grams per cent. Of the 13 cases with elevated total lipid, one had meningitis, 2 had pneumonia, 3 had jaundice with ascites and early cirrhosis, one had periportal fibrosis and cirrhosis, one had coronary sclerosis and one had tuberculosis. The increase in total lipid in these 13 livers was due to an increase in the neutral fat fraction. This is the type of change that is always found in fatty livers and is also seen in the livers of depancreatized dogs or dogs with ligated pancreatic ducts $(10,11)$. In the remaining 12 cases the total liver lipid varied from 2 to 7.07 grams per cent. Of these 12 cases, in addition to alcoholism, 3 were cardiacs, 2 died following an accident, 1 had a hypernephroma, 1 was a patient with hemochromatosis and diabetes who was admitted in ketosis and was kept on a low fat diet and insulin, 2 had portal cirrhosis and 3 cases were uncomplicated. The complications may have had some effect on the total amount of lipid in the liver, particularly when associated with malnutrition or low fat diets. Undoubtedly, in these cases the phase of fatty infiltration had preceded the cirrhotic stage. The total cholesterol, measured in 16 of the 25 livers, was above $300 \mathrm{mgm}$. per cent in 10 cases. In 8 cases this elevated cholesterol was in livers in which the total lipid was elevated. The elevation was due apparently to an increase in the esterified fraction, as the free cholesterol averaged $254 \mathrm{mgm}$. per cent. The increase of cholesterol in the fatty livers was not proportional to the increase in neutral fat, e.g., in Case 39 the neutral fat was 32.5 grams per cent and the total cholesterol was 317 mgm. per cent, whereas in Case 1, the neutral fat was 11.2 grams per cent and the total cholesterol was $406 \mathrm{mgm}$. per cent. In depancreatized dogs the cholesterol infiltration into the liver tends to parallel the fatty infiltration (10). The fact that this was not observed in this group of human livers may reflect the difference in the cholesterol content of the diet. Note should be taken of the fact that the majority of these patients had some other complication besides alcoholism.

In Table IV are reported the lipid values in 5 cases of cirrhosis of the liver uncomplicated by 
TABLE III

Liver lipids in alcoholic patients (25 cases)

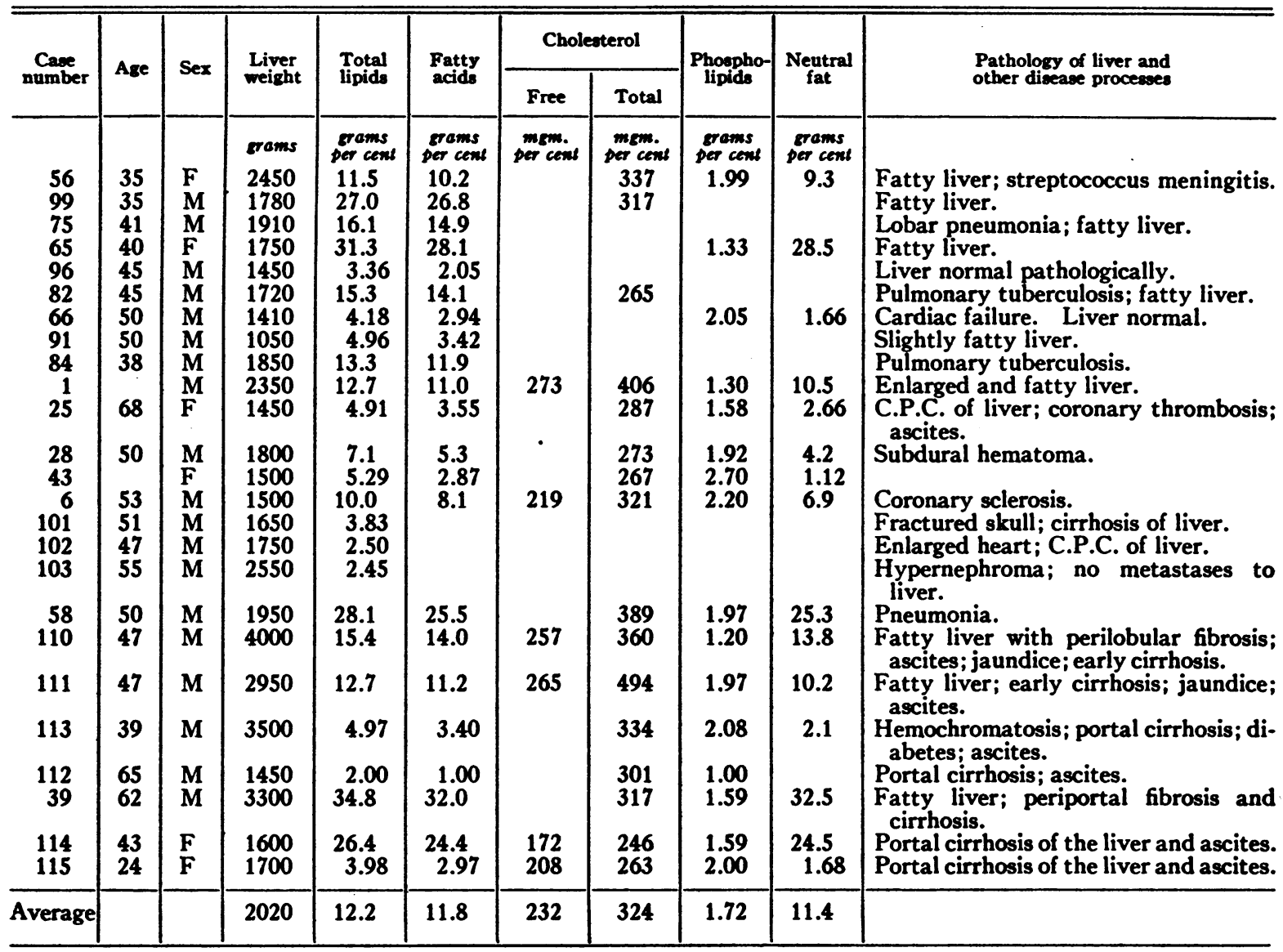

TABLE IV

Cases of cirrhosis of the liver uncomplicated by alcoholism

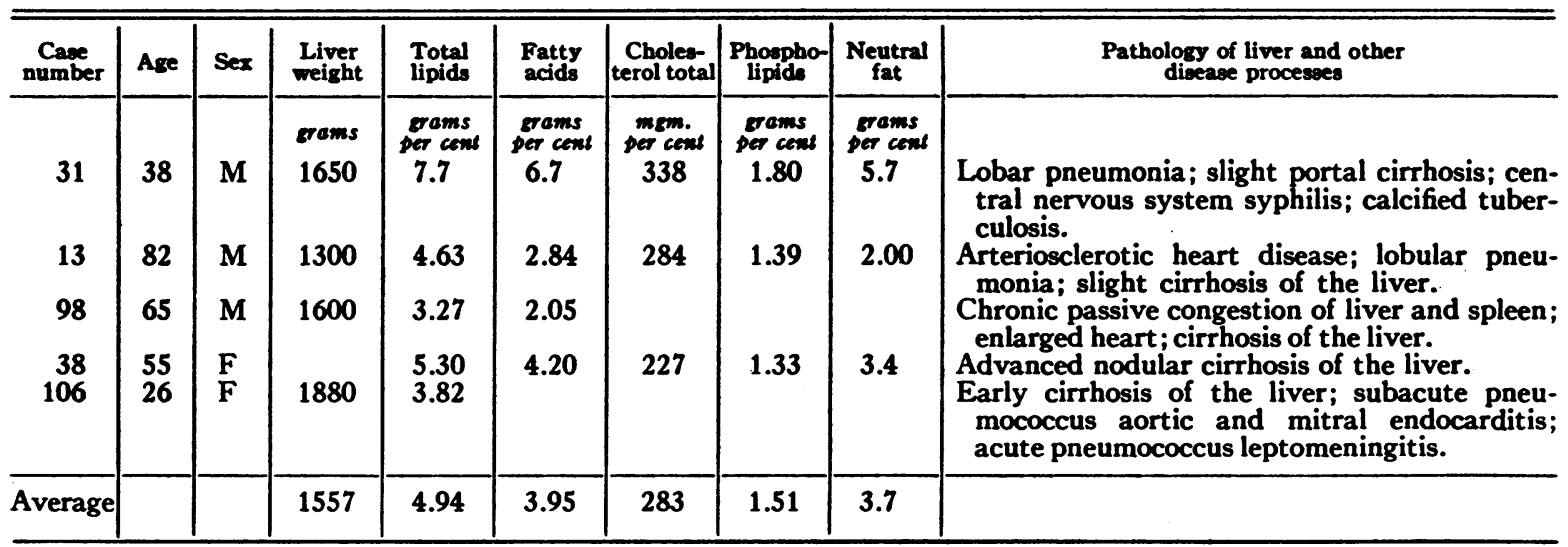


alcoholism. There was no elevation of the total lipid in this group, the highest total lipid being 7.68 grams per cent. The total cholesterol was done on 3 livers in this group and was within normal limits. If one assumes that cirrhosis of the liver is preceded by a period of fatty infiltration, these 5 cases should represent the end stage of the disease. Other factors, however, might account for the absence of fatty infiltration, e.g., malnutrition or infection. Of these 5 cases, Case 31 had lobular pneumonia, central nervous system syphilis, cerebral cortical atrophy, and an old calcified tuberculosis. The state of nutrition in spite of these complications was fairly good. Case 13 had arteriosclerosis and lobular pneumonia; the state of nutrition in this patient was good. Case 98 had an enlarged heart with evidence of congestive heart failure; the state of nutrition was fair. Case 38 had no complications, but microscopic sections of the liver showed cords of dense fibrous tissue and a marked alteration in the lobular architecture of this organ; the diagnosis in this case was advanced nodular cirrhosis; the state of nutrition was good. Case 106 was in a poor state of nutrition and had subacute pneumococcus aortic and mitral endocarditis, and acute pneumococcus leptomeningitis; the liver showed early cirrhosis. In 3 of these 5 cases, the degree of cirrhosis of the liver was not advanced. Obviously, this is too small a group from which to draw any definite conclusions, but it seems as if cirrhosis of the liver may occur without previous fatty infiltration. In only one case was the nutritional state really poor.

\section{DISCUSSION}

The average total liver lipid in the group of 25 normal livers was 4.98 grams per cent. This agrees with other published observations on human livers and is about the same as the values reported for other mammalian livers. In tissue sampled as this was at varying periods after death, approximately 45 per cent of the total lipid was neutral fat. This is somewhat higher than is found in fresh specimens of dog liver where the neutral fat is approximately 15 to 20 per cent (1).

In the group of patients with chronic alcoholism, fatty infiltration occurred in $\mathbf{5 0}$ per cent of the livers. This observation has been made before but chemical analyses give more definite evidence as to the varying degrees and the character of the fatty changes. Comparison of the individual and average figures in Tables II (normal) and III (alcoholic) shows changes in lipid distribution characteristic of fatty infiltration of the liver, viz., increase in total lipid due to accumulation of neutral fat, increase in cholesterol esters and a decrease in the concentration of phospholipids. The last may be a dilution phenomenon due to the increase in the size of the liver. The total amount of phospholipid in the entire liver is actually greater in the alcoholic than in the normal group.

The phospholipid values in the normal group cover $\dot{a}$ wider but lower range than was previously found in normal dogs on a high calorie, high vitamin diet (1). Apart from differences in the nutritional history, this finding is probably due in part to the postmortem action in the human livers of esterases which split part of the phospholipids so that the fragment containing the lipoid phosphorus is no longer soluble in petroleum ether, while the fatty acid moiety remains soluble ( $\mathrm{Ta}$ ble I). Hence, neutral fat values are apparently increased at the expense of phospholipids. Theis (6) also observed a higher ratio of neutral fat to phospholipids in normal human livers sampled at various intervals postmortem than is commonly found in normal animal livers that are analyzed shortly after excision.

Examination of Table I shows that there is approximately a 21 per cent decrease in the apparent phospholipid value within 24 hours after excision of the normal dog liver. If one assumed that an equal decrease occurred in these human livers and corrected for this decrease, the ratio would then approach that found in fresh tissue.

Observations such as these do not unfortunately shed any light on the mechanism of the production of this fatty infiltration of the liver in patients with histories of chronic alcoholism. Discussion of the etiology of this disorder must still rest on experimental data. As mentioned before, fatty infiltration of the liver can be produced experimentally in dogs by depancreatization, by ligation of the pancreatic ducts and by feeding an extreme high fat diet (14). It can be prevented in depancreatized or duct-ligated dogs by feeding raw 
pancreas or choline or by feeding water-extracted meat powder in place of raw meat. In addition, Dragstedt (15) has reported a pancreatic hormone (lipocaic) capable of preventing fatty infiltration of the liver but the hormonal nature of the extract used has not as yet been confirmed by other investigators. Whether or not the pancreas is involved in the production of the fatty liver in the alcoholic patient is purely a matter of speculation. Connor (16) has advanced the hypothesis that fatty infiltration of the liver in chronic alcoholism is associated with a disturbance of carbohydrate metabolism. This disturbance, he thinks, may be due either to carbohydrate depletion of the liver or to an interference with the normal utilization of carbohydrate.

The fact that all patients with histories of chronic alcoholism do not develop fatty livers suggests that alcohol alone may not be the sole factor responsible, but the question of why some alcoholic subjects develop this condition while others do not remains a problem that requires further study.

\section{SUM MARY}

The livers of 25 normal subjects, 25 alcoholic patients and 5 patients with no history of alcoholism but with cirrhosis of the liver were analyzed for their lipid content. The total lipid content of the normal human livers varied from 2.42 to $\mathbf{8 . 4 1}$ grams per cent. The average total cholesterol was $283 \mathrm{mgm}$. per cent. Of the 25 alcoholic patients 13 had liver lipids above 9 grams per cent. The average total cholesterol was above 300 mgm. per cent. The total liver lipid was not elevated in the patients with cirrhosis of the liver who were not alcoholics.

We are indebted to Dr. Douglas Symmers, Director of the Department of Pathology of Bellevue Hospital, and to the Department of Hospitals and the Office of the Chief Medical Examiner for the samples of liver obtained for analysis.

\section{BIBLIOGRAPHY}

1. Rubin, S. H., Present, C. H., and Ralli, E. P., The liver lipids in normal dogs on different types of fat, with and without added lecithin. J. Biol. Chem., 1937, 121, 19.
2. Kaplan, A., and Chaikoff, I. L., Liver lipids in completely depancreatized dogs maintained with insulin. J. Biol. Chem., 1935, 108, 201.

3. Ralli, E. P., Flaum, G., and Banta, R., The results of feeding lecithin and pancreas in depancreatized dogs on the liver fat and its saponifiable and unsaponifiable fractions. Am. J. Physiol., 1935, 110, 545.

4. Channon, H. J., Jenkins, G. N., and Smith, J. A. B., Deposition of fat in the liver and carcass of the rat on diets high in fat and low in lipotropic factors. Biochem. J., 1937, 31, 41.

5. MacLean, D. L., Ridout, J. H., and Best, C. H., The effects of diets low in choline upon liver function, growth and distribution of fat in the white rat. Brit. J. Exper. Path., 1937, 18, 345.

6. Theis, E., Lipid distribution in normal and abnormal liver tissue. III. The effect of disease upon the lipid distribution in human liver tissue. J. Biol. Chem., 1929, 82, 327.

7. Breusch, F., and Scalabrino, R., The quantitative distribution of liver lipids. Ztschr. f. d. ges. exper. Med., 1934, 94, 570.

8. Kennaway, E. L., and Leathes, J. B., A preliminary note on the examination of the fat in the liver in health and disease. Proc. Roy. Soc. Med., 1909, 2, 136.

9. Best, C. H., Ferguson, G. C., and Hershey, J. M., Choline and liver fat in diabetic dogs. J. Physiol., 1933, 79, 94.

10. Kaplan, A., and Chaikoff, I. L., The effect of raw and autoclaved pancreas on the liver lipids of the completely depancreatized dog maintained with insulin. J. Biol. Chem., 1937, 119, 435.

11. Ralli, E. P., Rubin, S. H., and Present, C. H., Liver lipids and fecal excretion of fat and nitrogen in dogs with ligated pancreatic ducts. Am. J. Physiol., 1938, 122, 43.

12. Montgomery, M. L., Entenman, C., and Chaikoff, I. L., The liver lipids of dogs subjected to ligation of the external pancreatic ducts. J. Biol. Chem., 1939, 128, 387.

13. Ralli, E. P., and Rubin, S. H., The effect of meat extract on fatty infiltration of the liver in depancreatized and duct-ligated dogs. Proc. Soc. Exper. Biol. and Med., 1940, 43, 601.

14. Chaikoff, I. L., and Connor, C. L., Production of cirrhosis of the liver of the normal dog by high fat diets. Proc. Soc. Exper. Biol. and Med., 1940, 43, 638.

15. Dragstedt, L. R., and others, Lipocaic and fatty infiltration of the liver in pancreatic diabetes. Arch. Int. Med., 1939, 64, 1017.

16. Connor, C. L., Fatty infiltration of the liver and development of cirrhosis in diabetes and chronic alcoholism. Am. J. Path., 1938, 14, 347. 